Studies in Contemporary History Series Editors. T. G. Fraser and J. O. Springhall

\author{
Published \\ T. G. Fraser The Arab-Israeli Conflict \\ Dennis B. Smith Japan since 1945: The Rise of an Economic \\ Superpower
}




\section{The Arab-IsRaeli Conflict}

T. G. Fraser

Macmillan Education 
ISBN 978-0-333-59023-2 ISBN 978-1-349-24143-9 (eBook)

DOI 10.1007/978-1-349-24143-9

\author{
THE ARAB-ISRAELI CONFLICT \\ Copyright $\odot 1995$ by T. G. Fraser
}

Softcover reprint of the hardcover 1st edition 1995

All rights reserved. No part of this book may be used or reproduced in any manner whatsoever without written permission except in the case of brief quotations embodied in critical articles or reviews.

For information, address:

St. Martin's Press, Scholarly and Reference Division, 175 Fifth Avenue, New York, N.Y. 10010

First published in the United States of America in 1995

ISBN 978-0-312-12757-2 (cloth)

ISBN 978-0-312-12759-6 (paper)

Library of Congress Cataloging-in-Publication Data

Fraser, T. G.

The Arab-Israeli conflict / T. G. Fraser.

p. $\mathrm{cm}$.

Includes bibliographical references and index.

ISBN 978-0-312-12757-2 (cloth). — ISBN 978-0-312-12759-6 (paper)

1. Jewish-Arab relations. 2. Israel-Arab conflicts. I. Title.

DS1 19.7.F725 1995

$956.04-\mathrm{dc} 20$

$95-15358$

CIP 
For Grace 


\section{Contents}

Series Editors' Preface

Acknowledgements

xii

Glossary

xiii

Map: Israel and its Arab Neighbours

XV

Introduction

The origins of the Arab-Israeli conflict 2

The impact of the First World War

The British Mandate over Palestine

The Holocaust

14

American Jewish Support for Zionism

1 The Partition of Palestine and the Creation of Israel

British and American Policies towards Palestine

The Anglo-American Committee of Inquiry 
The King David Hotel attack and its consequences 31 The UNSCOP report $\quad 34$

The UNSCOP report in the General Assembly 37

The end of the British Mandate 41

The proclamation of the state of Israel 44

The first Arab-Israeli war $\quad 45$

\section{The Problem Consolidated}

Israel after the 1948-9 war

The Palestinians after the 1948-9 war $\quad 55$

The Egyptian revolution

Deteriorating Arab-Israeli relations

61

The Gaza raid and its consequences

64

Origins of the Suez crisis

66

Nasser's nationalisation of the Suez Canal 68

'Collusion' and war

Consequences of the Suez crisis

73

Fatah and the Palestinian revival

Origins of the June war

The June war: Israel's six day victory

The aftermath of war

The Palestinian revival

The Israeli-American link

'Black September' in Jordan

Sadat's foreign policy

The Yom Kippur war

Kissinger and the ceasefire

Results of the war

Kissinger's 'step-by-step' diplomacy 
The PLO after the 1973 war

The PLO and the Lebanese civil war

Carter and the return to diplomacy

Menahem Begin's electoral triumph

Sadat's visit to Jerusalem

The Camp David summit

Reagan's Middle East policy

Israel's Lebanon war

America intervenes: the multinational force

The Reagan Peace plan

The Sabra and Shatila massacres

America's Lebanese débâcle

The Intifada

Moves towards a settlement

The Gulf war

The Bush-Baker initiative

The Breakthrough

Conclusion

Bibliography 


\section{Series Editors' Preface}

There are those, politicians among them, who feel that historians should not teach or write about contemporary events and people - many of whom are still living - because of the difficulty of treating such matters with historical perspective, that it is right to draw some distinction between the study of history and the study of current affairs. Proponents of this view seem to be unaware of the concept of contemporary history to which this series is devoted, that the history of the recent past can and should be written with a degree of objectivity. As memories of the Second World War recede, it is surely time to place in perspective the postwar history that has shaped all our lives, whether we were born in the 1940s or the 1970s.

Many countries - Britain, the United States and Germany among them - allow access to their public records under a thirty-year rule, opening up much of the postwar period to archival research. For more recent events, diaries, memoirs, and the investigations of newspapers and television, confirm the view of the famous historian Sir Lewis Namier that all secrets are in print provided you know where to look for them. Contemporary historians also have the opportunity, denied to historians of earlier periods, of interviewing participants in the events 
they are analysing. The problem facing the contemporary historian is, if anything, the embarrassment of riches.

In any case, the nature and extent of world changes since the late 1980s have clearly signalled the need for concise discussion of major themes in post-1945 history. For many of us the difficult thing to grasp is how dramatically the world has changed over recent years: the collapse of the Soviet Union and Russian communism; the end of Soviet hegemony over eastern Europe; the unification of Germany; the end of the Cold War; America's sense of a 'new world order'; the pace of integration in the European Community; the disintegration of Yugoslavia; the Middle East peace settlement; the continuing economic strength of Japan. Writing in a structured and cogent way about these seismic changes is what makes contemporary history so challenging, and we hope that the end result will convey some of this excitement and interest to our readers.

The general objective of this series, written entirely by members of the School of History, Philosophy and Politics of the University of Ulster, is to offer concise and up-to-date treatments of postwar themes considered of historical and political significance, and to stimulate critical thought about the theoretical assumptions and conceptual apparatus underlying interpretation of the topics under discussion. The series should bring some of the central themes and problems confronting students and teachers of recent history, politics and international affairs into sharper focus than the textbook writer alone could provide. The blend required to write contemporary history that is both readable and easily understood but also accurate and scholarly is not easy to achieve, but we hope that this series will prove worthwhile for both students and teachers interested in world affairs since 1945.

University of Ulster

T. G. Fraser

John Springhall 


\section{ACKNOWLEDGEMENTS}

I acknowledge the permission of the Controller of $\mathrm{Her}$ Majesty's Stationery Office for permission to quote Crown Copyright material.

I am grateful to Keith Kyle and Paul Lalor for commenting on parts of my manuscript. Responsibility for interpretation is my own. 


\section{GLOSSARY}

Aliyah term for immigration (technically 'ascent') of Jews into the Land of Israel

A'yan Arab 'notables' of Palestine, e.g. the Husseinis Diaspora term for the 'Dispersion' of the Jews

Fatah 'Movement for the Liberation of Palestine', principal Palestinian group, founded by Yasser Arafat

Gush Emunim 'Block of the Faithful', a movement in the 1970s and 1980s to settle Jews in the Occupied Territories

Haganah 'Defence', the official defence force of the Jewish Agency which formed the basis of the Israeli army

Hibbat Zion 'The Love of Zion', movement to settle Russian Jews in Palestine in the 1880s

Intifada 'Uprising', used for the revolt in the Occupied Territories which began in 1987

Irgun Zvai Leumi 'National Military Organisation', right-wing underground army led by Menahem Begin

Knesset name for the Israeli parliament or assembly

Leh'i 'Fighters for the Freedom of Israel', right-wing underground group sometimes known as the Stern Gang after its founder Avraham Stern

Likud 'Union', right-wing political coalition led by Menahem Begin 


\section{Glossary}

Mesha'a system of landholding in Palestine

Yishuv term for the Jewish community in Palestine before 1948 


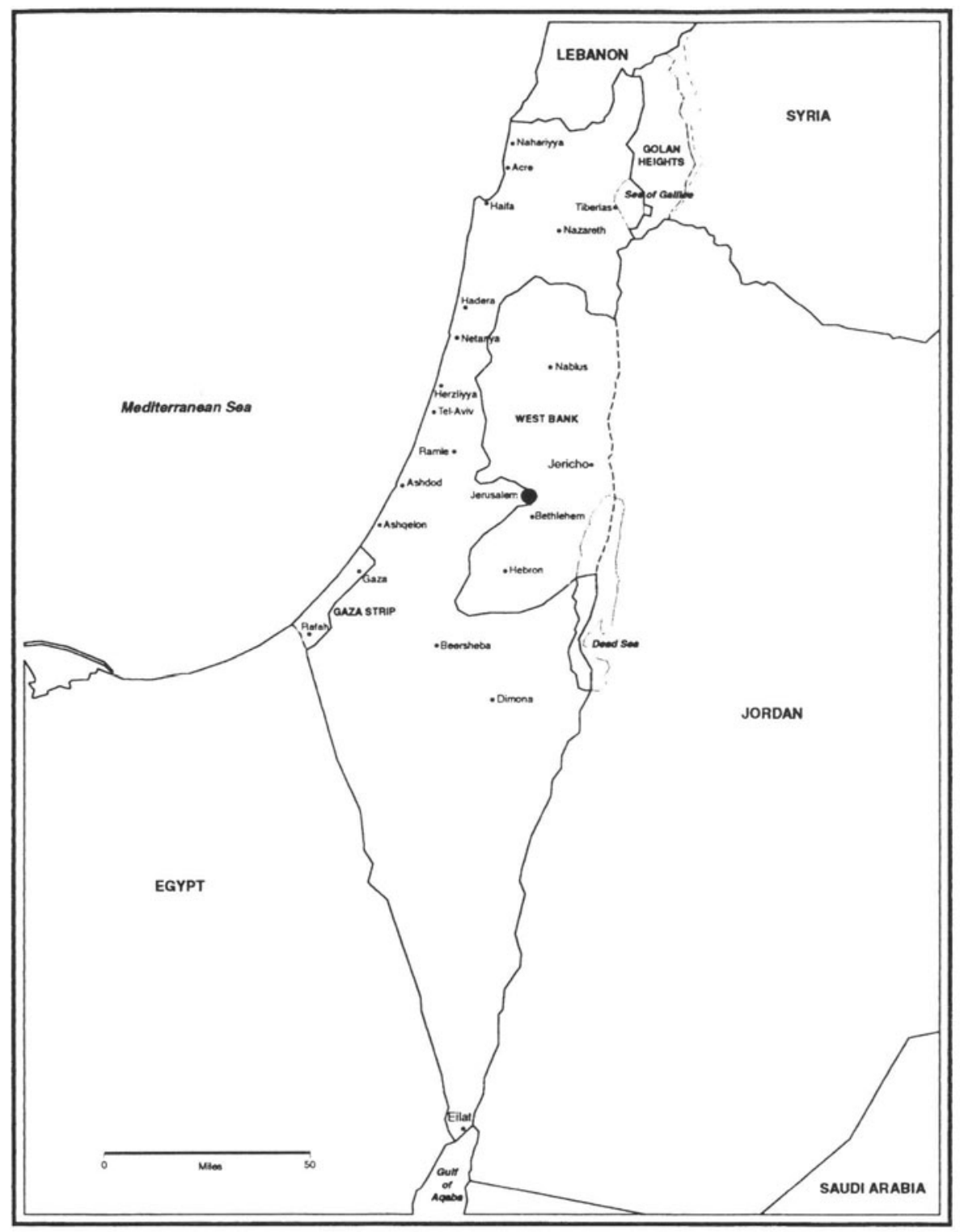

Israel and its Arab Neighbours 